\title{
Temperature Inverted Haloclines Provide Winter Warm-Water Refugia for Manatees in Southwest Florida
}

\author{
Bradley M. Stith • James P. Reid • Catherine A. Langtimm • Eric D. Swain • \\ Terry J. Doyle • Daniel H. Slone $\cdot$ Jeremy D. Decker $\cdot$ Lars E. Soderqvist
}

Received: 21 September 2009 /Revised: 3 December 2009/Accepted: 4 March 2010/Published online: 21 April 2010

(C) The Author(s) 2010. This article is published with open access at Springerlink.com

\begin{abstract}
Florida manatees (Trichechus manatus latirostris) overwintering in the Ten Thousand Islands and western Everglades have no access to power plants or major artesian springs that provide warm-water refugia in other parts of Florida. Instead, hundreds of manatees aggregate at artificial canals, basins, and natural deep water sites that act as passive thermal refugia (PTR). Monitoring at two canal sites revealed temperature inverted haloclines, which provided warm salty bottom layers that generally remained above temperatures considered adverse for manatees. At the largest PTR, the warmer bottom layer disappeared unless significant salt stratification was maintained by upstream freshwater inflow over a persistent tidal wedge. A detailed three-
\end{abstract}

\section{B. M. Stith $(\bowtie)$}

Jacobs Technology, contracted to U.S. Geological Survey,

Southeast Ecological Science Center,

2201 NW 40th Terrace,

Gainesville, FL 32605, USA

e-mail: bstith@usgs.gov

J. P. Reid · C. A. Langtimm • D. H. Slone

U.S. Geological Survey, Southeast Ecological Science Center,

2201 NW 40th Terrace,

Gainesville, FL 32605, USA

E. D. Swain · J. D. Decker

U.S. Geological Survey, Florida Water Science Center,

3110 SW 9 Avenue,

Fort Lauderdale, FL 33315, USA

T. J. Doyle

U.S. Fish and Wildlife Service,

4401 N. Fairfax Dr., MS-MBSP-4107,

Arlington, VA 22203, USA

L. E. Soderqvist

U.S. Geological Survey, Florida Water Science Center - Ft. Myers,

3745 Broadway, Ste. 301,

Fort Myers, FL 33901, USA dimensional hydrology model showed that salinity stratification inhibited vertical convection induced by atmospheric cooling. Management or creation of temperature inverted haloclines may be a feasible and desirable option for resource managers to provide passive thermal refugia for manatees and other temperature sensitive aquatic species.

Keywords Thermal inversion · Halocline - Stratification . Passive thermal refugia - Picayune Strand restoration. Everglades restoration - Aerial survey - Satellite telemetry Climate change $\cdot$ Aquatic species

\section{Introduction}

The distribution of aquatic organisms frequently is limited by seasonal temperature extremes, and many species depend on thermal refugia to survive in key portions of their range (Matthews 1998). The Florida manatee (Trichechus manatus latirostris) is a federally and state-listed endangered species (U.S. Fish and Wildlife Service 2001) that has a limited tolerance for the cold water temperatures that occur regularly in the subtropical climates of Florida and the southeastern USA. During severe winter periods, manatees are restricted to peninsular Florida and must take refuge in warm-water sites to survive adverse winter temperatures (Lefebvre et al. 1989). This tropical-derived species has unusually low-heat production capacity and high-thermal conductance that limits its ability to thermoregulate in cold water (Irvine 1983). Manatees can suffer acute mortality during severe cold fronts, and die-offs have been documented in Florida as far south as Miami and Flamingo (Moore 1951; Hartman 1979). Even winters without extreme cold events can produce pathological features in manatees described as "cold stress syndrome" (Bossart et al. 2003), which may affect fecundity 
and long-term survival. When water temperatures fall below $20^{\circ} \mathrm{C}$, they seek out warm water (Hartman 1979; Shane 1984). Captive manatees feed erratically in $15-20^{\circ} \mathrm{C}$ water, may refuse to eat at $15-18^{\circ} \mathrm{C}$ (Campbell and Irvine 1981), and after 2 or 3 days begin to show signs of shivering, anorexia, and changes in behavior (Bossart 2001). General agreement exists among these studies that temperatures falling below a threshold of $20^{\circ} \mathrm{C}$ become increasingly stressful for manatees (Laist and Reynolds 2005a).

In northern coastal Florida, harsh water temperatures occur throughout much of the winter, and manatees congregate in warm-water refugia at large artesian springs and discharge outlets at power plants (Laist and Reynolds 2005a). Coastal south Florida has few such sources of warm water, and manatees are commonly seen taking shelter in natural deep water areas and manmade canals and basins (Laist and Reynolds 2005a). Because these sites have no major source of warm-water influx, they are generally known as passive thermal refuges (PTRs). PTRs may become increasingly important for manatees in the near future due to power plant shutdowns or failing springs (U.S. Fish and Wildlife Service 2001). Loss of warm-water sites has been identified as a major threat to manatee population recovery (U.S. Fish and Wildlife Service 2001; Runge et al. 2007). Surprisingly little is known about PTRs used by manatees, and understanding those in South Florida may be especially important since they may provide inadequate protection for manatees during severe winters (Laist and Reynolds 2005a, b).

The PTR with the highest manatee counts in the state is in Southwest Florida at Port of the Islands (POI; Fig. 1), Collier County, which commonly has aggregations of 100 or more manatees (U.S. Fish and Wildlife Service 2001). POI is a residential development that includes a system of dredged canals and a marina basin that receives freshwater discharge from an extensive canal system directly upstream. The area upstream of POI is part of the Picayune Strand Restoration Project (PSRP), a high priority state sponsored (Acceler8) project that is currently under construction by the U.S. Army Corp of Engineers and the South Florida Water Management District as part of the restoration efforts of the Comprehensive Everglades Restoration Plan (CERP). Restoration is expected to alter the hydrologic conditions in the region and at POI, potentially affecting the warm-water characteristics for manatees and other species (U.S. Army Corp of Engineers and South Florida Water Management District 2004; Swain and Decker 2009). State and federal management agencies charged with recovery of listed species and with implementation of the CERP require an understanding of the role and impact of warm-water refugia in reducing mortality risks.

This research is part of an ongoing U.S. Geological Survey (USGS) effort to predict hydrologic changes associated with the PSRP and model potential manatee response to these changes (Swain and Decker 2009; Langtimm et al. 2009). Our primary objective was to provide a better understanding of the hydrodynamics of PTRs in the study area. We used data from aerial surveys to identify key manatee aggregation sites and satellite telemetry data to analyze movement patterns in response to changing water temperatures. We monitored vertical temperature and salinity at the two largest PTRs and compared the temporal variation in winter water temperatures among different regional types of water bodies also frequented by manatees. The empirical data showed that PTRs provided unusually warm bottom temperatures during cold periods, leading us to hypothesize salinity stratification as a mechanism for maintaining otherwise unstable temperature inversions. We calculated water densities for our surface and bottom measurements to test whether salinity stratification could establish stable density distributions that would support temperature inversions. We used a complex three-dimensional hydrology model of POI to test whether the proposed mechanism of salinity stratification could produce the patterns in water temperatures observed in this major PTR.

\section{Materials and Methods}

\section{Study Area}

The study area encompasses the southern coastal region of Collier County, FL, USA centering on the Ten Thousand Islands (TTI) region, extending from the northwest portion of Everglades National Park westward to Marco Island (Fig. 1). The extent of the study area was dictated in part by manatee movements documented for radio-tagged individuals for this research. This area is a shallow, subtropical estuarine system consisting of tidally influenced rivers which discharge into inland bays enclosed by numerous mangrove islands. The coastal margin is fronted by shallow flats of the Gulf of Mexico. Tidal range is classified as microtidal $(<1 \mathrm{~m}$; Browder et al. 1986). Public-owned areas used by manatees include the Ten Thousand Islands National Wildlife Refuge, Everglades National Park, Rookery Bay National Estuarine Research Reserve, CollierSeminole State Park, Fakahatchee Strand Preserve State Park, and Big Cypress National Preserve.

Two PTRs in the central portion of the study area were a special focus of this research: POI, at the north end of the Faka Union canal, and Big Cypress National Preserve (BCNP) headquarters (Fig. 1), which consists of canals that receive freshwater inflow from the upstream Big Cypress basin, and tidal inflow downstream from Halfway Creek. The area around POI is heavily influenced by the $77-\mathrm{km}$ Faka Union canal system which was completed in 1971 to drain a failed real estate development, now slated for 
Fig. 1 Study area showing the two largest passive thermal refugia (Port of the Islands and Big Cypress National Preserve headquarters) and the hydrologic monitoring stations (1-Port of the Islands, 2-Big Cypress National Preserve headquarters, 3-Faka Union Bay, 4-Fakahatchee Bay). A monitoring station for the Gulf of Mexico was located off the map $18 \mathrm{~km}$ northwest of Marco Island at the Naples pier

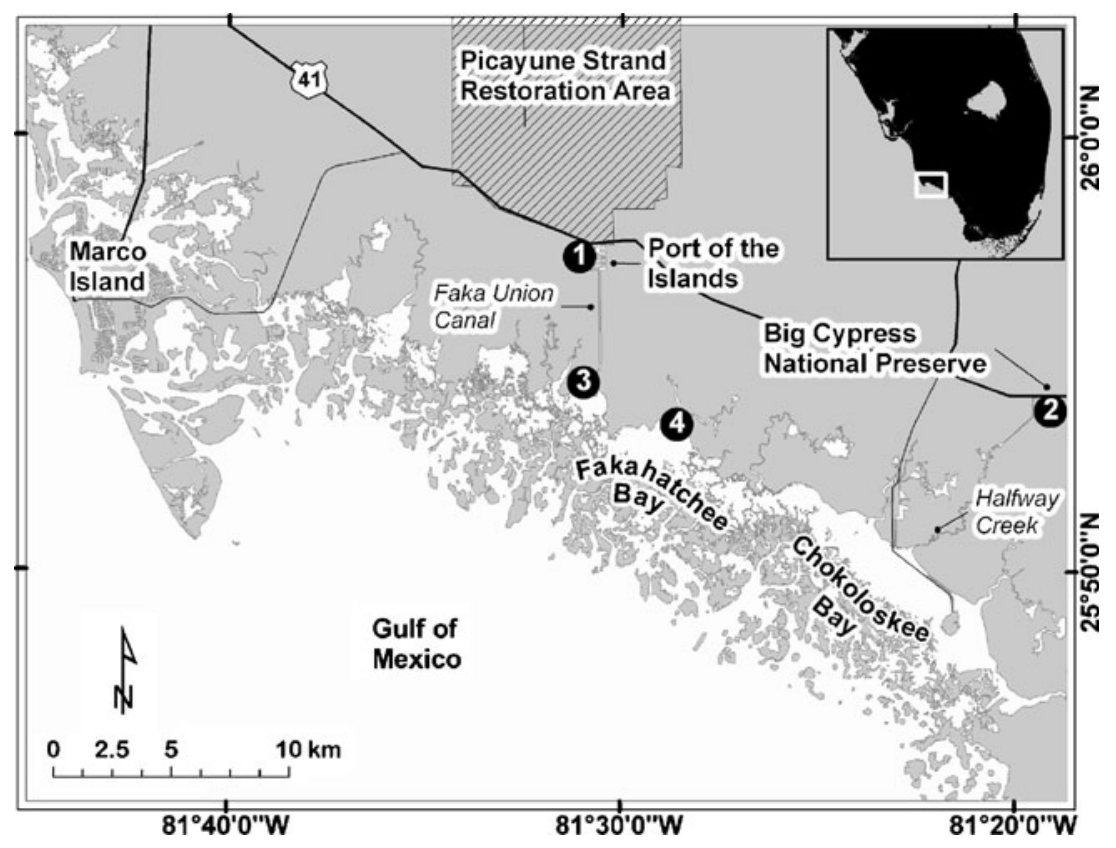

restoration (U.S. Army Corp of Engineers and South Florida Water Management District 2004; Swain and Decker 2009). The canal system intercepts sheet flow and rapidly diverts large water volumes as point discharge out the Faka Union Canal and into the Gulf of Mexico. Weirs were built to prevent over drainage during the dry season, but the canals have resulted in a general lowering of the water table, reduced groundwater seepage, and a shortened hydro-period (U.S. Army Corp of Engineers and South Florida Water Management District 2004). The southernmost weir restricts tidal incursion to the lower $7 \mathrm{~km}$ of the Faka Union canal (except during extreme tides or storm events).

\section{Manatee Habitat Use}

Although POI has long been known as an important manatee winter aggregation site (U.S. Fish and Wildlife Service 2001), we used aerial surveys and satellite telemetry to provide greater detail of current manatee habitat use within the region. To analyze the data, we divided the landscape into habitat patches and assigned each patch to one of four general zones for GIS analyses of manatee habitat use and movement. These zones were: (1) inland (rivers, canals, and basins); (2) enclosed bays; (3) inter-island corridors (channels and open areas between mangrove islands); and (4) offshore (shallow, near shore Gulf of Mexico; Fig. 2).

To identify areas of heavy use by manatees during winter, synoptic aerial survey data (Ackerman 1995) were obtained for the study region from 1991 to 2007 (FWRI 2009; four incomplete surveys were deleted). These surveys were flown as part of a statewide program using a standardized protocol and flight line that includes all of the major river systems, inland bays, and shallow Gulf shoals in the study area.

The aerial survey point data were overlaid with the habitat patches, and the results were summarized by zone and major winter aggregation sites. The summary data provide minimum counts of animals at surveyed sites, and underestimate the true population size by an unknown amount.

Winter telemetry data were available for 22 manatees captured and tagged at POI between 2001 and 2006 and provided data at a finer temporal and spatial resolution than aerial surveys. Data were obtained from floating Argos platform transmitter terminals (PTT; Telonics, Inc.) or GPS units (Lotek Wireless, Inc. or Telonics, Inc.) attached to manatees by flexible tethers to standardized peduncle belts (Reid et al. 1995). Argos location fixes were calculated from transmissions received by polar-orbiting satellites during four programmed duty cycles daily, potentially providing four standard quality locations per day. GPS location data were collected at time intervals ranging from 15 to $60 \mathrm{~min}$.

Telemetry data were reduced to winter months only (November through March). Locational accuracy for the Argos data has a known variability, and only the two most accurate location classes (LC3, LC2) were kept: Service Argos, Inc. (1996) estimates that 68\% of locations should lay within $150 \mathrm{~m}$ for LC3 and within $350 \mathrm{~m}$ for LC2. Data were further reduced to one location class per programmed duty cycle (Deutsch et al. 2003). The GPS data were subsampled to one location per 6-h interval approximating the Argos satellite fix intervals, and all winter location data from both tag types were merged for analysis. 
Fig. 2 Study area map showing habitat zones (offshore, corridor, bay, and rivers/canals) used in GIS analyses. Named sites had relatively high counts of manatees during winter synoptic aerial surveys (1999-2007)

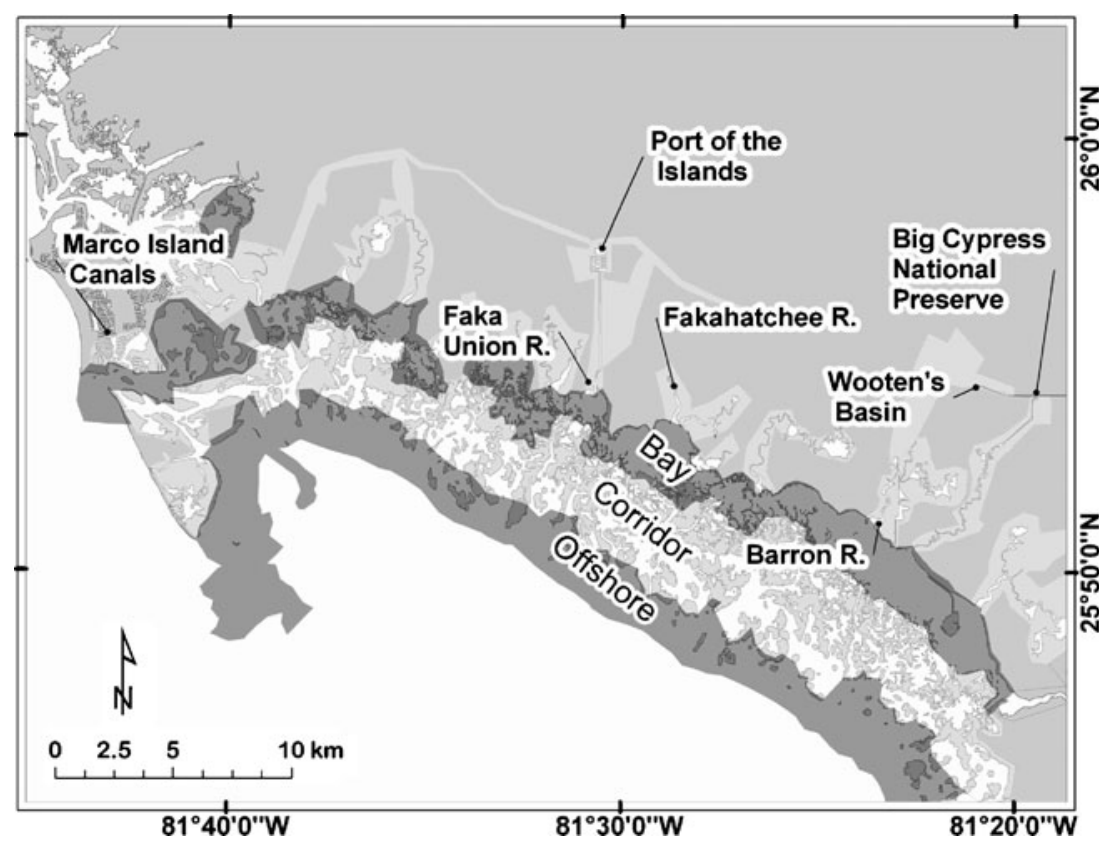

GIS overlay procedures (ArcGIS identity function, E.S.R.I. 1997) were used to assign telemetry locations to one of the four habitat zones, river systems or canals, bays, inter-island corridors, and offshore (Fig. 2). We interpolated hourly Gulf temperatures to match date and time for each telemetry fix. The proportional manatee use of each habitat zone at different Gulf temperatures was calculated at $1^{\circ} \mathrm{C}$ intervals from $14^{\circ} \mathrm{C}$ to $27^{\circ} \mathrm{C}$.

To investigate whether tagged manatees showed preferential use of different habitat zones based on water temperature, we calculated kernel density surfaces for each animal-winter combination using Gulf temperature to segregate the telemetry locations into three Gulf temperature bins: less than $18^{\circ} \mathrm{C}, 18^{\circ} \mathrm{C}$ to less than $20^{\circ} \mathrm{C}$, and $20^{\circ} \mathrm{C}$ or above. We used the Home Range Extension for ArcView (Rodgers and Carr 1998) with a fixed kernel $(500 \mathrm{~m})$ for the utilization distribution (Worton 1989) and least square cross validation for the smoothing parameter (Silverman 1986). We summed the resulting surface grid files for all animals tracked for each threshold temperature bin, treating each animal-winter-temperature bin combination as a single sample. Maps were displayed using the 50th and tenth percentile contour levels to show moderately and heavily used areas.

\section{Hydrodynamic Thermal Properties}

Collection of Environmental Data To investigate differences in thermal properties among the different water bodies frequented by manatees, data on water and air temperature, rainfall, salinity, flow, and stage in different habitat zones around the study area were obtained from permanent or temporary monitoring stations from several agencies (see Acknowledgments). Near-bottom temperatures were measured at all stations; surface temperatures were only available for the PTRs at POI and BCNP.

The PTRs were continuously monitored by USGS during four winters to characterize the vertical temperature regime. Temperature dataloggers (HOBO Water Temp v2 and Tidbit, Onset Computer Co., Pocasset, MA, USA) at near-surface and near-bottom depths recorded temperatures at 15 min intervals during two winters (2004/2005-2005/2006). These temperature-only probes were replaced by four YSI 600 XLM water quality sondes (YSI Incorporated, 1700 Brannum Lane, Yellow Springs, OH 45387-1107; www.ysi.com). Two probes were deployed at each site, within $15 \mathrm{~cm}$ of surface using a floating mount, and within $15 \mathrm{~cm}$ of the bottom. Date/time, temperature, conductance, and salinity (calculated using temperature and conductance) were logged every $30 \mathrm{~min}$ in subsequent winters (2006/2007-2007/2008).

Comparison of Thermal Properties of Gulf, Bay, and PTR Water Bodies Hourly temperature data for seven site-depth locations (Fig. 1; POI top/bottom, BCNP top/bottom, Faka Union Bay, Fakahatchee Bay, Naples) representing key water bodies (PTR top/bottom, bay, and Gulf) for four winters (2004/2005-2007/2008) were analyzed to test for differences in water temperature as they related to temperature thresholds. We used the Kruskal-Wallis test followed by the NemenyiDamico-Wolfe-Dunn test (joint ranking; Hollander and Wolfe 1999) as implemented in the COIN library in $\mathrm{R}$ (Hothorn et al. 2008). To reduce the influence of warm periods on the results, the data were filtered to include only those periods when one or more sites fell below the $20^{\circ} \mathrm{C}$ 
manatee temperature threshold. This truncation resulted in strongly left-skewed distributions. Data were further filtered to obtain equal sample sizes among sites by rejecting any date-time where data were missing for one or more stations. To compare annual variation in winter water temperatures among the seven site-depth locations, we calculated the number of hourly readings at $1^{\circ} \mathrm{C}$ increments to provide an index of exposure time to different temperatures.

Analysis of Temperature and Salinity Profiles at the PTRS To portray relationships among temperature and salinity, data for the two PTRs were plotted in vertical panels for the 2 years with salinity data. Mean daily discharge over the Faka Union weir also was plotted for POI (data were unavailable for BCNP).

Vertical Density Profiles at the PTRs We calculated in-situ densities for surface and bottom layers at POI using the "International Equation of State of Water" (Fofonoff and Millard 1983) based on temperature, salinity, and pressure. These density calculations were used to examine whether density gradients associated with salinity stratification could offset opposing density gradients associated with temperature inversions. Changes in density result in fall turnover in lakes due to surface-water cooling (Reid and Wood 1976), and density gradients are commonly used to index the role of stratification in resisting turnover (Dyer 1997). For each bottom-surface measurement, we calculated and plotted the vertical difference in temperature and salinity for each paired sample. We overlaid this plot with a contoured surface of density differences to show the relationship between the vertical differences in density associated with vertical differences in salinity and temperature. The contoured surface of vertical density differences was generated as a least squares trend surface (six degree polynomial) using the "MASS" library in R (Venables and Ripley 2002).

Correlation analyses were conducted for data at POI to examine relationships among three key factors: (1) temperature difference (bottom-surface), (2) salinity difference (bottom-surface), and (3) freshwater discharge at the POI weir. The data were filtered to periods when the surface temperature fell below the threshold values of $18^{\circ} \mathrm{C}$ or $20^{\circ} \mathrm{C}$.

Numerical Hydrology Modeling To examine whether mechanisms associated with salinity and temperature stratification identified by analysis of the monitoring data could produce the observed patterns in water temperatures, we simulated conditions at POI with and without salinity stratification using a three-dimensional hydrodynamic model application of the Environmental Fluid Dynamics Code (EFDC) from the Virginia Institute of Marine Science (Hamrick 1992; U.S. Environmental Protection Agency 2002). This application of the EFDC model at POI is part of a larger project to investigate different restoration scenarios; here, we were only interested in comparing the POI system in the presence or absence of salt stratification. Because the physics-based EFDC application simulates the transport of variable density fluid in three dimensions, and explicitly models temperature and salinity, we viewed the model as an independent means of evaluating the patterns and mechanisms identified from the monitoring data at POI.

The three-dimensional application used a curvilinear grid with 104 columns and 50 rows (1,750 active cells) representing POI (Fig. 3). Grid size varied within the approximate range of 10-20 $\mathrm{m}$ with an average measurement of approximately $15 \mathrm{~m}$. The northern boundary of active cells had a no-flow boundary representing the tideblocking weir just north of POI. Volumetric sources were placed within the upper layers of the northern most cells to represent flow over the weir and into the canal. Boundaries for the northern flow volumes overtopping the weir were taken from South Florida Water Management District's Database, DBHYDRO. The southern boundary was a water surface elevation boundary positioned approximately $130 \mathrm{~m}$ south of the port exit. The southern surface boundary water levels and the northern and southern salinity and temperature values were taken from a two-dimension surfacewater/groundwater model of the TTI area (Swain and Decker 2009). Model bathymetry was determined by acoustic surveys and was defined by mean depth values.

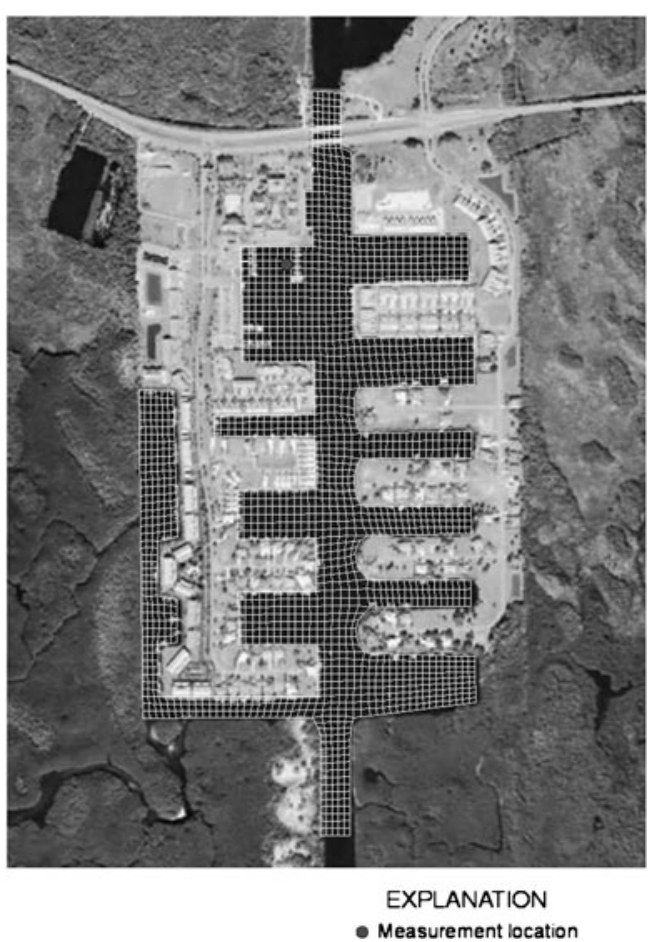

Fig. 3 Map of Port of the Islands showing grid for three-dimensional hydrology model application. North end of grid is a tidal-blocking weir. Major east-west road is U.S. 41 
General model input parameters, such as cell friction, heat transfer and evaporation coefficients, and vertical and horizontal diffusion, were initially determined from standard values and previous EFDC model applications and then adjusted for better model fit. The model requires extensive atmospheric data, including rain volumes, wind speed and direction, solar radiation, and air temperature, which was obtained from the Florida Automated Weather Network. Five vertical layers were used for the majority of testing and calibration and gave adequate representation of the vertical stratification of salinity and temperature.

Two simulations were run with and without the density effects of salinity variations over a 242-day time period (1 September 2004 to 30 April 2005). The salinity stratification used was relatively small compared to observed conditions, with the surface and bottom layers differing by about $8 \mathrm{psu}$. More recent periods could not be simulated due to the unavailability of key field measurements more recent than 2005 .

\section{Results}

Manatee Aerial Surveys The winter aerial surveys analyzed at the patch level showed the largest minimum mean counts of manatees at four major winter aggregation sites (Table 1): POI (94.1 \pm 54.8$)$, BCNP (19.5 \pm 7.8$)$, Marco Island canals (15.5 \pm 13.1$)$, and Wooten's $(13.4 \pm 10.4)$. All four sites consist of artificial canals and basins. At the broader landscape scale, minimum mean manatee counts were much higher in the inland zone than the other three zones (Table 2). Several minor noncanal sites were also identified, including the Fakahatchee River (likely associated with scoured portions of the river), the southern remnant of the Faka Union River, and the mouth of the Barron River.

Telemetry The winter telemetry data showed a strong decrease in manatee use of Gulf waters as Gulf temperature decreased (Fig. 4). The proportion of tag locations found at inland and bay sites increased substantially as winter Gulf temperatures decreased. No manatees were recorded in Gulf waters less than $15^{\circ} \mathrm{C}$.

Table 1 Synoptic survey mean minimum counts (1991-2007) at the major passive thermal refugia (PTRs) in the study area

\begin{tabular}{lcrrr}
\hline Location & Mean count & SD & Min & Max \\
\hline Port of the Islands & 94.1 & 54.8 & 30 & 225 \\
Big Cypress & 19.5 & 7.8 & 1 & 38 \\
Marco Island & 15.5 & 13.1 & 1 & 55 \\
Wooten's & 13.4 & 10.4 & 4 & 45 \\
\hline
\end{tabular}

Table 2 Synoptic survey mean minimum counts (1991-2007) within regional landscape zones

\begin{tabular}{lrrrr}
\hline Habitat Zone & Mean count & SD & Min & Max \\
\hline River/Canal & 154.7 & 71.2 & 54 & 340 \\
Bay & 16.0 & 13.5 & 3 & 48 \\
Offshore & 11.9 & 22.0 & 1 & 78 \\
Corridor & 4.1 & 4.7 & 1 & 18 \\
\hline
\end{tabular}

Kernel densities of manatee locations showed high use of inland sites during winter when Gulf temperatures were at or below $20^{\circ} \mathrm{C}$, and much greater use of offshore areas when Gulf temperatures were above $20^{\circ} \mathrm{C}$ (Fig. 5). Total area of medium and high densities became progressively smaller and shifted inshore as Gulf temperature decreased from $20^{\circ} \mathrm{C}$ to below $18^{\circ} \mathrm{C}$.

\section{Temperature Comparisons Among Water Bodies}

The PTR bottom temperatures were significantly warmer than any other water bodies. Kruskal-Wallis comparison of temperatures below the $20^{\circ} \mathrm{C}$ threshold at the seven sitedepth localities for the four winters showed significant differences $\left(X^{2}=12,723.46 ; p<0.0001\right)$. Ranking the median temperature values showed that the bottom layers at the PTRs were the warmest among sites $\left(\mathrm{BCNP}=25.73^{\circ} \mathrm{C}\right.$; $\mathrm{POI}=22.26^{\circ} \mathrm{C}$ ), followed by the two PTR surface layers (BCNP surface $=20.45^{\circ} \mathrm{C}$; POI surface $=20.38^{\circ} \mathrm{C}$ ), Fakahatchee Bay $\left(20.0^{\circ} \mathrm{C}\right)$, Faka Union Bay $\left(19.30^{\circ} \mathrm{C}\right)$, and the Gulf $\left(18.21^{\circ} \mathrm{C}\right)$. Post hoc comparisons showed that only the two PTR surface layers were not significantly different.

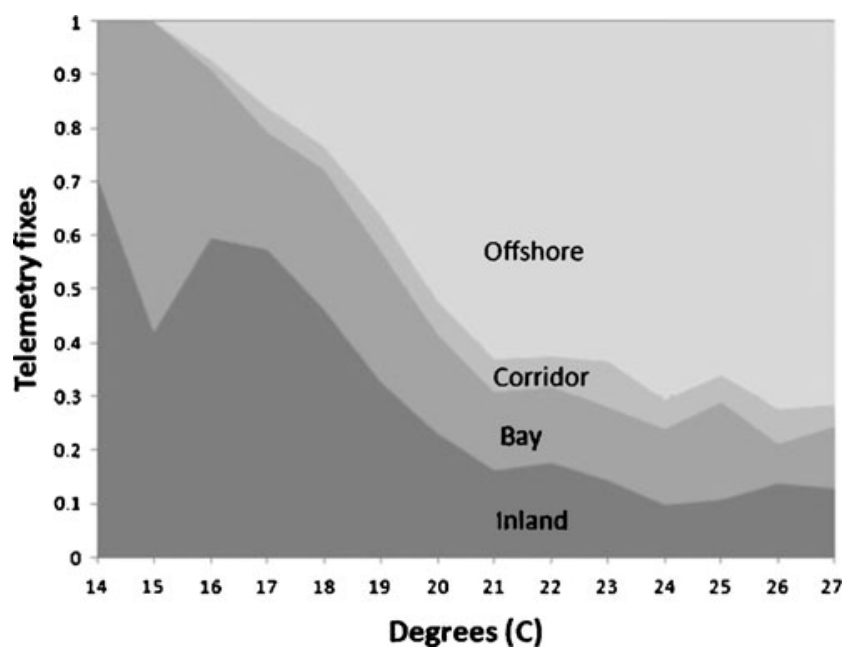

Fig. 4 Proportion of telemetry fixes in four landscape zones (offshore, inter-island corridors, bay, and inshore) at $1{ }^{\circ} \mathrm{C}$ Gulf temperature intervals for 22 radio-tagged manatees during winter, 2001-2007 
When the dataset was reduced to days when no salinity stratification was present at POI, post-hoc comparisons from the Kruskal-Wallis test showed that the surface and bottom layers no longer differed from each other, but were still warmer than the two nearby bays.

The distribution of $1{ }^{\circ} \mathrm{C}$ interval winter hourly readings for the seven site-depth stations showed that the bottom layers at PTRs had many fewer readings below $20^{\circ} \mathrm{C}$ than other water bodies (Fig. 6). Only the bottom layer at BCNP showed no readings below $20^{\circ} \mathrm{C}$. The POI bottom layer showed the next warmest distribution, with the winter of
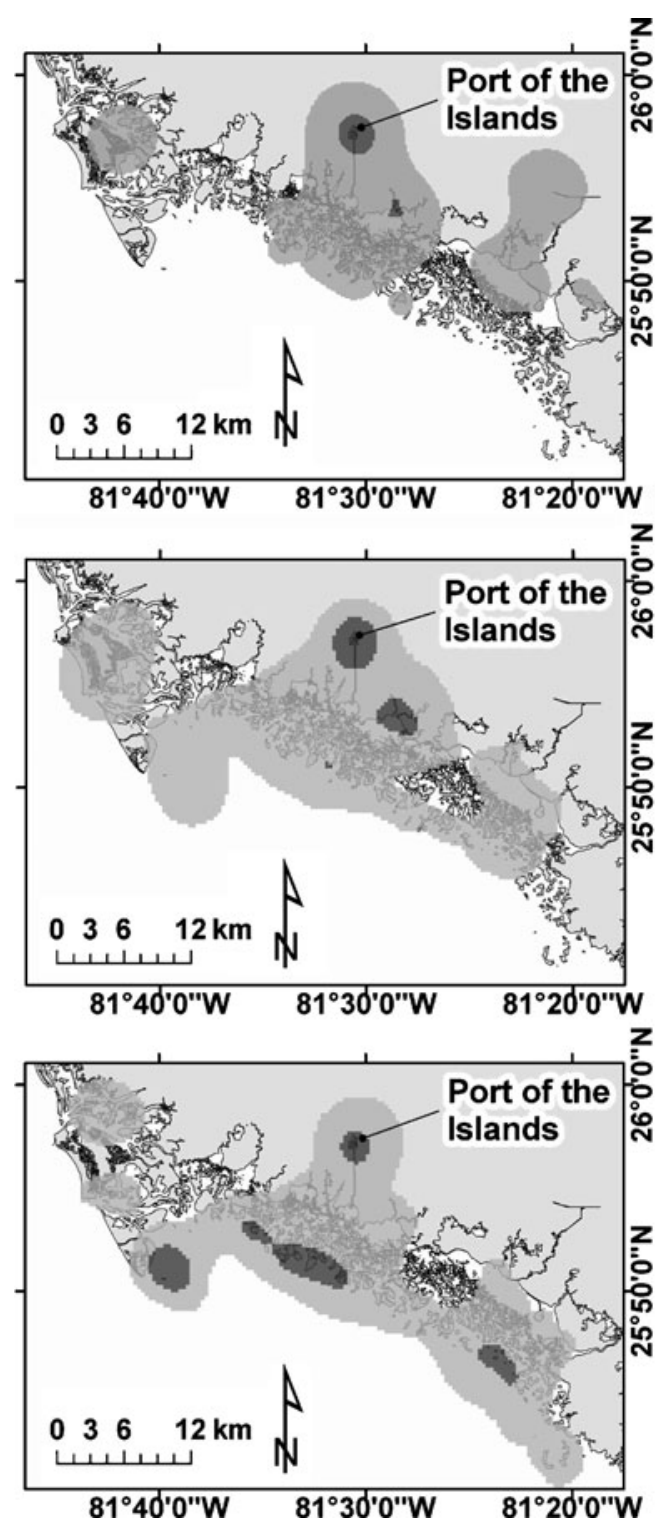

Fig. 5 Composite of individual kernel location surfaces for 22 radiotagged manatees during winter, 2001-2006, for three Gulf temperature ranges (upper map: less than $18^{\circ} \mathrm{C}$; middle map: $18^{\circ} \mathrm{C}$ to $20^{\circ} \mathrm{C}$; lower map: greater than $20^{\circ} \mathrm{C}$ ). High (black - upper $10 \%$ threshold) and moderate (gray- $50 \%$ threshold) use regions shift from inshore to offshore as Gulf temperatures increase
2004/2005 showing substantially more cold readings than the other three winters. Fakahatchee and Faka Union Bay showed the most extreme temperatures, while the Gulf showed the largest number of days below $20^{\circ} \mathrm{C}$.

Temperature Inversions and Stratification

Thermal inversions were prevalent at both PTRs and provided warm bottom temperatures even when surface temperatures fell below $20^{\circ} \mathrm{C}$ (Figs. 7 and 8). The BCNP bottom layer temperature was extremely stable (Fig. 8), whereas the POI bottom layer showed significant fluctuations (Fig. 7). The POI bottom layer occasionally fell below $20^{\circ} \mathrm{C}$, but did so only when no halocline was present (Fig. 7). Comparison of periods when haloclines were present or absent show strikingly different temperature fluctuations in the bottom layer. When haloclines were absent, the bottom layer can be seen fluctuating and falling below $20^{\circ} \mathrm{C}$ in near synchrony with the surface, as in the 54-day period from 19 December to 12 February 2008 (Fig. 7). Freshwater discharge was low and declining during this period. A large winter storm greatly increased discharge and reestablished the halocline on 12 February 2008 (Fig. 7), followed by a 6-week period (13 February31 March 2008) of strong temperature inversions where the bottom remained warm while the surface regularly fell below $20^{\circ} \mathrm{C}$.

The magnitude of the thermal inversion at POI was strongly correlated with the magnitude of the salinity gradient when surface temperatures were below $20^{\circ} \mathrm{C}$ or $18^{\circ} \mathrm{C}$ (Fig. 9). The correlation was strongest when surface temperatures were below $18^{\circ} \mathrm{C}$ (Pearson's coefficient $=$ $0.898, \mathrm{df}=169, p<0.0001)$, and only slightly weaker when surface temperatures were below $20^{\circ} \mathrm{C}$ (Pearson's coefficient $=0.714, \mathrm{df}=711, p<0.0001)$. When no halocline was present, thermal inversions were small or absent, as can be seen from the large cluster of data points occurring near the origin, representing periods when the vertical temperature and salinity gradient was minimal (Fig. 9).

The magnitude of the salinity gradient was strongly correlated with upstream freshwater discharge over the POI weir (Fig. 10; Pearson's coefficient $=0.8215, \mathrm{df}=222, p<$ $0.0001)$. Reduced discharge was associated with loss of the halocline, indicating that freshwater discharge is important for maintaining salinity stratification. The correlation between freshwater discharge and vertical temperature difference was much weaker (Pearson's coefficient $=0.368$, $\mathrm{df}=222, p<0.0001)$.

A source of bottom heat at POI is strongly indicated by day-long or longer periods when the bottom layer was warming while the surface layer was rapidly cooling (e.g., arrows in Fig. 7). The source of this heat was unknown, but could be due to factors such as groundwater influx, 
Fig. 6 Count of hourly water temperatures during winter (December-February) at five monitoring sites. Bottom temperatures measured at all sites, surface measurements measured at POI and Big Cypress only. Counts are for readings falling within $1{ }^{\circ} \mathrm{C}$ temperature intervals between $12^{\circ} \mathrm{C}$ and $30^{\circ} \mathrm{C}$ for 4 years (years shown as separate lines: $l=2004 / 2005,2=2005 / 2006$, $3=2006 / 2007,4=2007 / 2008$ ). For comparison purposes, a horizontal line equivalent to 10 days (240 hourly readings) is shown

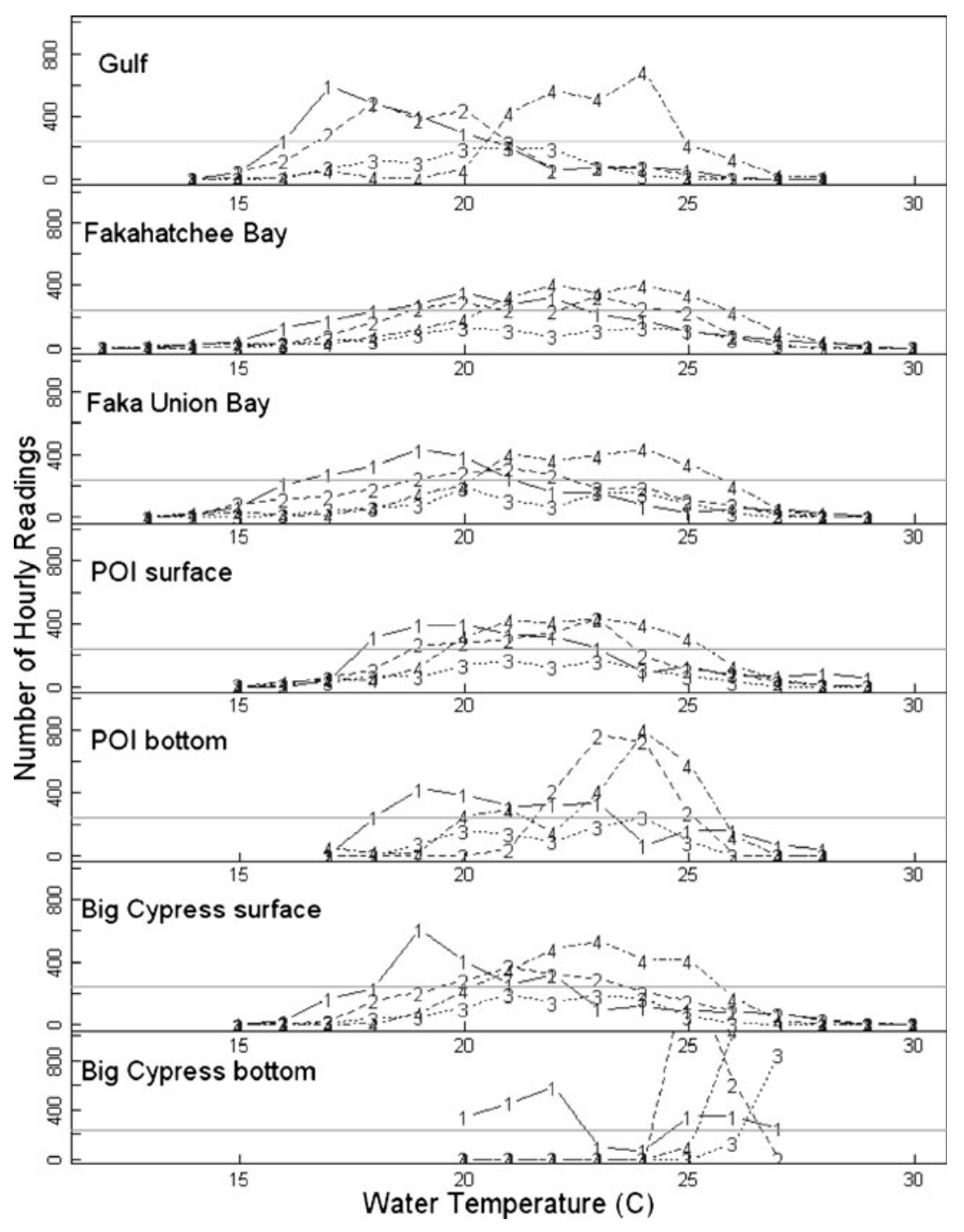

conductive subsurface heat flux, or heat generated by microbial activity. We currently lack data to evaluate these possible heat sources.

\section{Density Relationships Associated with Stratification}

Density calculations showed that the density gradient developed a more stable distribution (bottom denser than surface) as salinity differences increased, even during severe cold periods when the surface temperature was much colder than the bottom (over $8^{\circ} \mathrm{C}$; Fig. 9). Salinity had a stronger influence on density than temperature across the observed range, and relatively small haloclines provided larger density differences that offset those resulting from strong temperature inversions. When density differences were close to zero (Fig. 9), temperature and salinity gradients were weak or absent, indicating a well-mixed water column associated with rapid turnover.

\section{Numerical Modeling}

The numerical modeling results of the physics-based EFDC application showed that salinity stratification was necessary to produce temperature inversions and maintain a warmbottom layer (Fig. 11). Inversions were largest between 11 to 18 December 2004 and 14 to 21 January 2005, corresponding to the arrival of a cold front and subsequent cooling of the surface water (Fig. 11, top panel). Temperature inversions were practically nonexistent, and the bottom temperatures were colder (Fig. 11, bottom panel), without the modeled density effects of salinity. The threedimensional model results showed that vertical convection rapidly mixed the water column under typical winter conditions. Introduction of relatively minor salt stratification resulted in a decoupling of the surface and bottom layers and provided biologically significant thermal inversions throughout the simulation period. 
Fig. 7 POI flow over weir (daily), surface and bottom salinity (hourly), and surface and bottom temperature (hourly) for winter 2006/2007 and 2007/ 2008. Arrows on temperature graph for 2007 show periods when the bottom layer was warming while surface layer was cooling. Note that heavy rain event occurred 11-12 February 2008

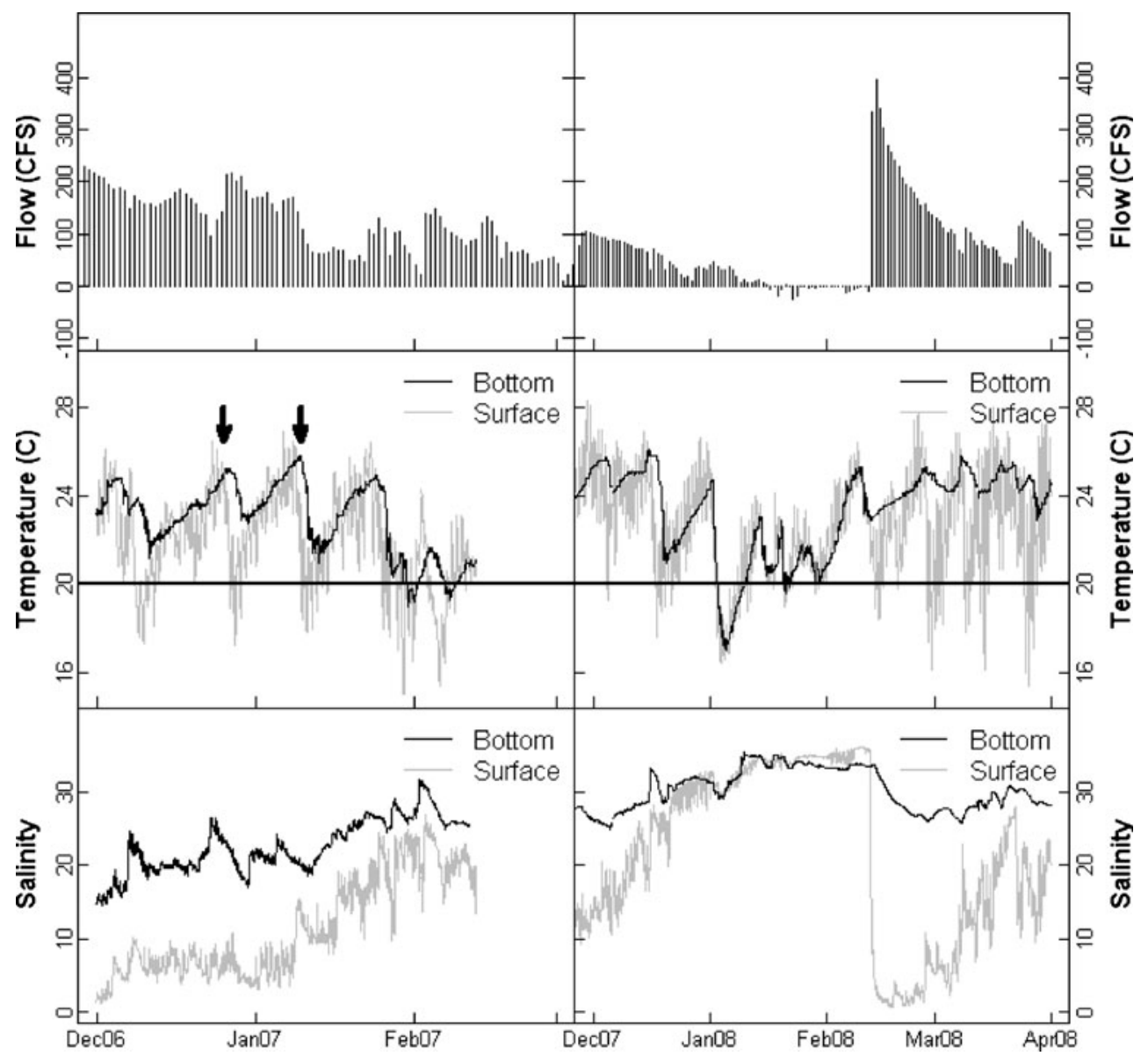

was readily identified in comparisons of the densities of the surface and bottom under different conditions. Buoyancy differences between strata suppress vertical flux of heat, substances and momentum (Kimmerer 2004), and the stability of stratified water bodies is proportional to the size of the vertical density differences between strata (Dyer 1997; Mann and Lazer 2006). During cold periods at POI, the warmer bottom layer was considerably denser than the cooler surface water, but only when there was a significant salinity gradient. Haloclines maintained a stable density gradient despite the temperature inversion, thus preventing vertical mixing. This finding was supported by the POI three-dimensional model, which showed that convective turnover rapidly cooled the bottom in the absence of salinity stratification. Within the typical range of salinity and temperature gradients observed at POI, salinity had a much greater impact on density than temperature, enabling haloclines to offset the potentially unstable density differences caused by temperature inversions (Fig. 9). Other things being equal, these density relationships show how temperature inverted haloclines can have stable density gradients that are resistant to vertical mixing.

The formation and maintenance of salinity stratification at POI during winter was strongly correlated with the amount of upstream freshwater discharged over the south- 
Fig. 8 BCNP surface and bottom salinity (hourly) and surface and bottom temperature (hourly) for winter 2006/2007 and $2007 / 2008$

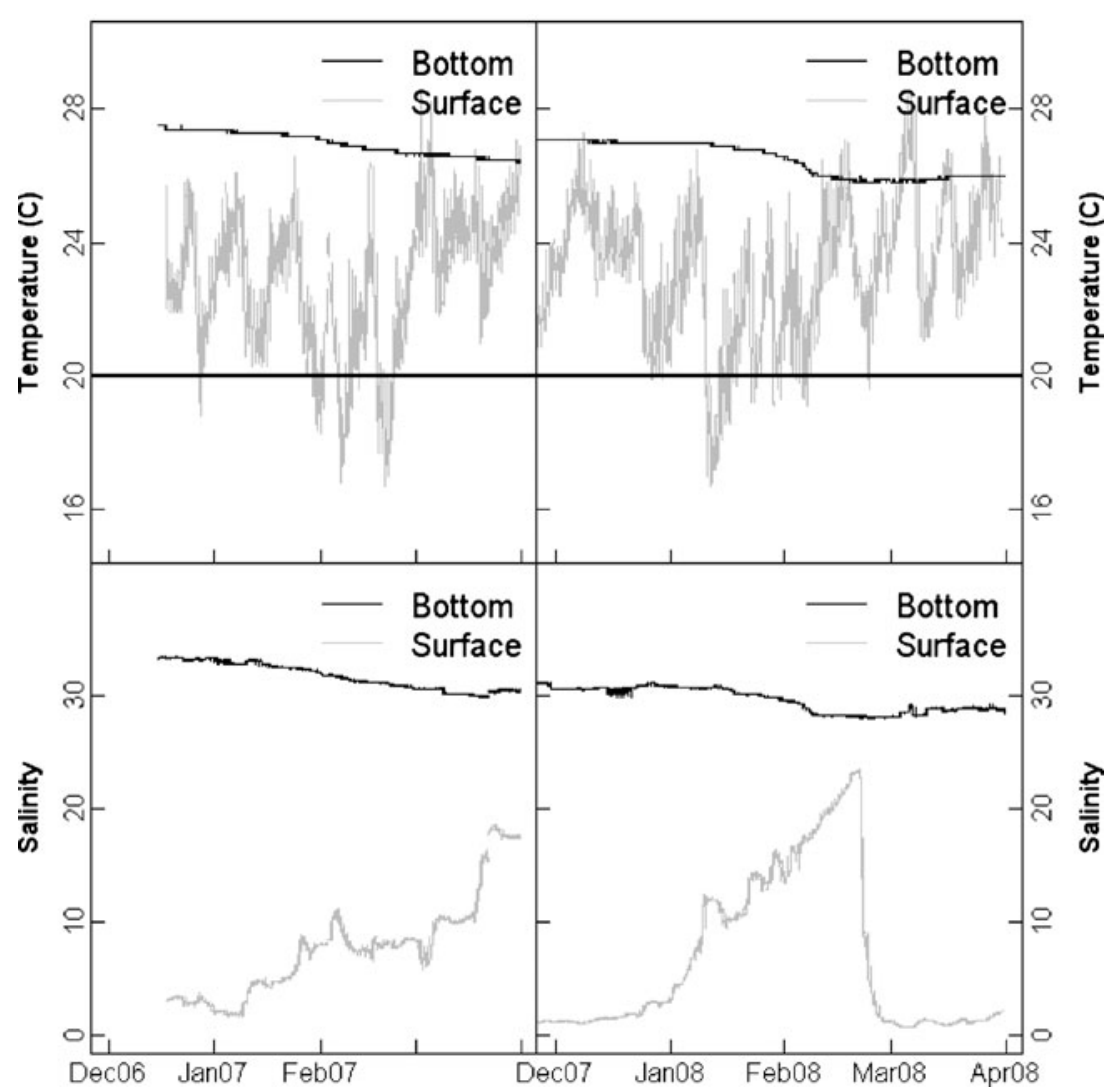

ern Faka Union weir (Fig. 10). Freshwater inflow is a key determinant of stratification in many estuarine systems (Ibanez et al. 1997; Dyer 1997) and appears to be important at POI. Under low or no-flow conditions, the stratification decreased fairly rapidly over time as the surface salinity approached the higher values of the bottom layer (Fig. 7). Tidal movement, direct bay connection, and high salinities suggest the bottom layer functions as a tidal wedge which entrains and mixes with the overlying freshwater, making the PTRs analogous to "salt-wedge estuaries" (Ibanez et al. 1997) or highly stratified systems (Dyer 1997). In such systems, an "estuarine circulation" pattern is established where the lighter freshwater layer flows seaward above a saltwater layer which is propagated upstream by tidal forcing (Kurup et al. 1998). Under such conditions, salinity stratification typically increases as freshwater discharge increases (Xu et al. 2008). At high levels of freshwater discharge tidal salinities can be eliminated (Hamilton et al. 2001). During the wet season, the entire Faka Union canal system has been observed to be oligohaline (Surge and Lohmann 2002). Nonetheless, bottom salinities at the PTRs remained high during all observed winters and were unaffected by discharge from a large storm event (Fig. 7; February 2008). At POI, the strong correlation between winter discharge and salinity stratification (Fig. 10) indicates that haloclines break down without adequate levels of freshwater discharge.
Several other mechanisms also can disrupt haloclines and impact temperature inversions in PTRs. Wind and wave action can create strong mixing effects, especially in open water bodies, but these factors are reduced in narrow estuaries or canals with limited fetch (Hamilton et al. 2001; Shafland 1995). Tides can disrupt stratification (Dyer 1997), but flushing within canals is reduced with increased depth, increased length, and bathymetry features (U.S. Environmental Protection Agency 1975; Luther et al. 2004). Localized stratification behind sills and in holes can be especially resistant to flushing (Kurup and Hamilton 2002; Luther et al. 2004), and even where bottom topography is smooth, stratification can persist in the face of large tides (Dyer 1997).

Groundwater discharge in rivers or estuaries can disrupt or maintain stratification, depending on salinity differences between the groundwater and receiving water body (Linderfelt and Turner 2001). Data on groundwater discharge at POI and BCNP were unavailable; however, the canals north of the weir at POI are thought to be deep enough to penetrate the surficial aquifer system and provide some connectivity (U.S. Army Corp of Engineers and South Florida Water Management District 2004). Canal systems in South Florida are known to act as conduits for tidal saltwater intrusion (Fitterman and Deszcz-Pan 2001; Price and Swart 2006), and aquifer discharge can act to recirculate intruded saltwater (Smith and Turner 2001). 
However, if groundwater discharge occurred at POI, the high bottom salinity measured during all winters indicate that the discharge did not disrupt the halocline. Although we lack data on groundwater exchange or other processes that might provide a source of heat, our analysis indicates that convective turnover eliminates any bottom warmth unless salinity stratification is present.

The temperature and salinity dynamics at these PTRs differ somewhat from the only other detailed study of a manatee PTR - the Matlacha Isles canal system (Barton 2006) - some $80 \mathrm{~km}$ north of Marco Island. No significant influx of freshwater was found at the surface or bottom, and opportunistic salinity sampling showed little or no stratification. The Matlacha PTR had warmer bottom temperatures than other nearby water bodies, but bottom temperatures fell below $18^{\circ} \mathrm{C}$ during multiple cold periods. Barton (2006) concluded that the warmer temperatures may be due to heat retention associated with two traits: deeper canals and lower tidal flushing. POI and BCNP are similar to Matlacha in having deep canals (2-4 $\mathrm{m}$ range) and relatively low tidal range compared to canal depth that can reduce tidal flushing (Dyer 1997). Greater canal depth also contributes to heat retention, since narrow canal width and relatively greater depths result in smaller surface-to-volume

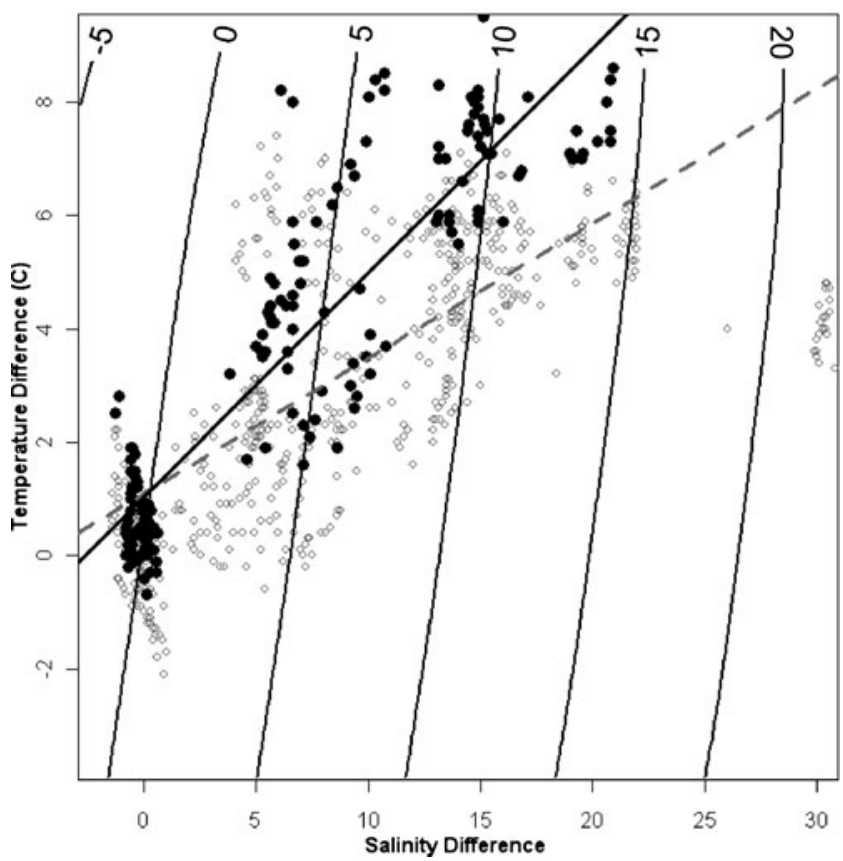

Fig. 9 POI salinity differences (bottom-surface) vs. temperature differences (bottom-surface) and correlations when surface temperatures were below $18^{\circ} \mathrm{C}$ (solid black circles and black correlation line) or below $20^{\circ} \mathrm{C}$ (small gray circles and gray dashed correlation line) for winter 2006/2007 and 2007/2008. Points with positive temperature differences indicate temperature inversions. Contours show calculated density differences $\left(\mathrm{kg} / \mathrm{m}^{3}\right.$; bottom-surface). Points to the right of the zero contour show increasingly stable density differences (bottom denser than surface)

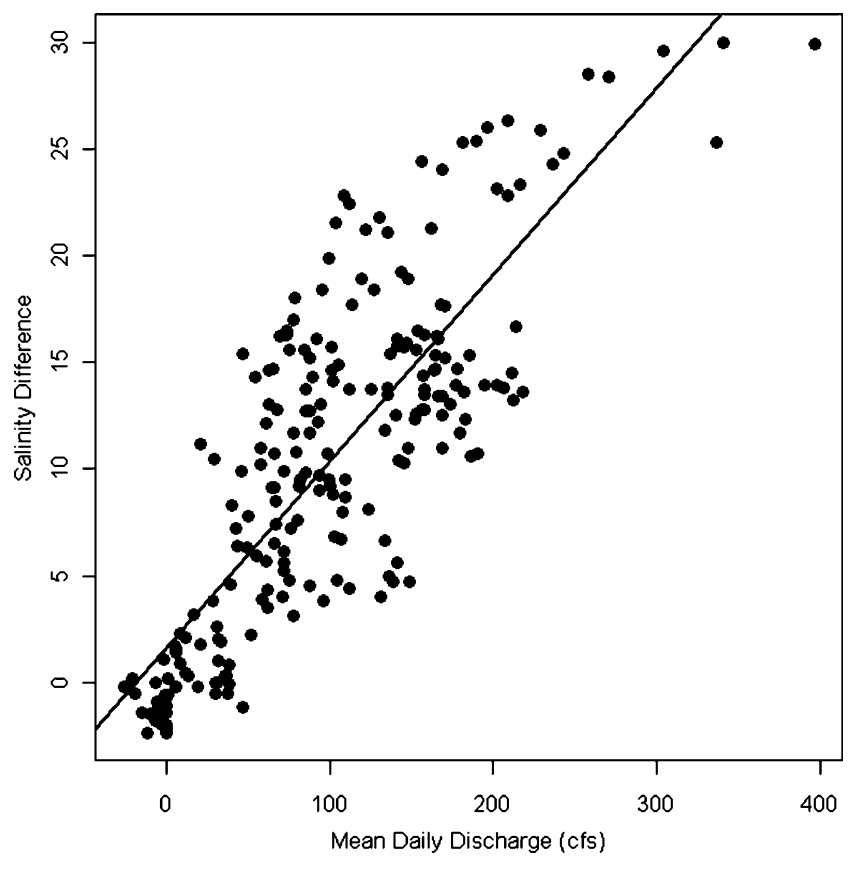

Fig. 10 Correlation between salinity difference (near bottom-near surface) vs. freshwater discharge at POI for winter 2006/2007-2007/2008

ratios, reducing heat loss compared to more open water bodies. This geometric relationship may explain why both POI surface and bottom layers were warmer than nearby bay waters, even when haloclines were absent. Nonetheless, the monitoring data and three-dimensional modeling clearly

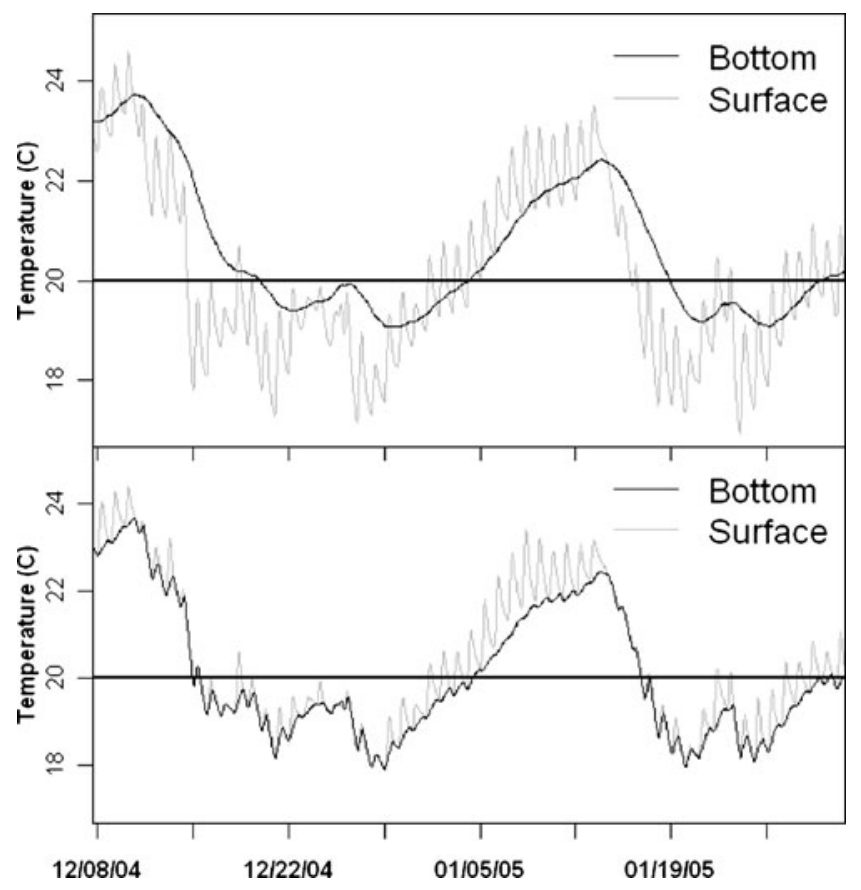

Fig. 11 Simulated top and bottom temperatures when salinity density effects were included (upper figure) or excluded (bottom figure) in the three-dimensional model of POI 
showed that salinity stratification dominated the warmwater dynamics at POI.

These relationships between temperature inversion, haloclines, and freshwater discharge have implications for potential impacts of the Picayune Strand Restoration on the warm-water characteristics at POI. The PSRP is expected to significantly reduce the discharge of freshwater into POI during the winter dry season (U.S. Army Corp of Engineers and South Florida Water Management District 2004; Swain and Decker 2009). Restoration will plug or fill most of the canals north of POI, redistribute much of the freshwater over a broader area via spreader canals, and establish sheet flow that will eventually discharge into other drainages in addition to POI. The slower drainage associated with sheet flow should raise water tables and allow more groundwater seepage, resulting in a prolonged hydro-period extending well into the dry season (U.S. Army Corp of Engineers and South Florida Water Management District 2004). Restoring predrainage conditions could improve freshwater flow at minor manatee aggregation sites that may function as natural PTRs. Possible examples include a scoured channel at the Fakahatchee River and deeper river sections in the southern Everglades (Stith et al. 2006). We suspect that natural PTRs may have been much more prevalent in South Florida prior to drainage projects, which reduced sheetflow during winter months. Restoring sheetflow could increase stratification at natural sites, improving winter conditions for manatees. However, reduction in freshwater discharge to POI could alter salinity stratification at this major warm-water refuge, degrading winter conditions for manatees. A comprehensive USGS effort based on the three-dimensional POI and two-dimensional regional hydrology models is underway (Swain and colleagues) to model potential impacts and address some of these issues.

If planned restoration would negatively impact POI for manatees, management options could be developed based on this study and additional modeling efforts. The mechanisms that maintain warmer water at PTRs seem amenable to artificially managing conditions or even engineering new PTRs. A major management objective might be to maintain sufficient levels of salinity stratification to support temperature inversions during winter. Discharging sufficient volumes of fresh or brackish water at the surface over tidal water may quickly establish a barrier to vertical mixing, providing a "blanket" effect (as well as drinking water for manatees). Limiting surface discharge to brief periods prior to advancing cold fronts might suffice if water scarcity is an issue. Increasing basin or canal depths can reduce tidal flushing and mixing and can increase thermal inertia. Creating an uneven bottom with deeper holes may provide pockets that resist tidal mixing and establish better connection with warm groundwater. The canal bathymetry at POI has some deeper pockets where manatees appear to aggregate more densely (pers. obs.). Creating conditions that favor stratification might conflict with managing water quality in canal systems experiencing hypoxia and eutrophication (U.S. Environmental Protection Agency 1975; Luther et al. 2004), although such problems typically do not arise during the winter. Additional monitoring and modeling are needed to further evaluate warm-water dynamics at POI and other PTRs.

Our results suggest that the PTRs we monitored can provide adequate warm water for manatees during typical winters when significant salinity stratification is present. Without salinity stratification, even typical winter conditions resulted in adversely cold water temperatures at POI. Under severe cold, stronger vertical mixing would be expected, and lack of salinity stratification at POI would likely result in severe temperatures throughout the water column. POI may be unsuitable as a warm-water refuge under these conditions. Further modeling efforts also might suggest how to design a PTR pilot study and could ultimately lead to a PTR management system that uses weather forecasts and realtime monitoring of salinity and temperature stratification to maximize thermal protection for manatees while efficiently managing freshwater discharge.

Understanding and managing the hydrodynamics of thermal refugia for aquatic organisms is becoming increasingly important for preserving endangered species (Schaefer et al. 2003; Torgersen et al. 1999) and limiting the spread of invasive species (Trexler et al. 2000). Here, we addressed warm-water refugia for a cold-intolerant species, but similarly cold-water refugia can be important to heat sensitive species that seek out cool bottom waters in the face of increased water temperatures associated with factors such as climate change, thermal effluent, and dam construction. Cool bottom waters have been observed at PTRs during summer, and salinity stratification may further enhance the stability of summer thermoclines. In the face of global climate change and rising sea levels, passive thermal refugia could provide vulnerable populations with respites during periods of extreme temperatures, possibly giving them time to respond and adapt to climate change effects (Baron et al. 2008). Determining effective ways to manage haloclines and thermoclines could prove to be an important option for resource managers by providing critical warm- or cold-water refugia for a wide variety of temperature sensitive aquatic species.

Acknowledgments We wish to thank the following agencies for hydrology or environmental data: South Florida Water Management District, Rookery Bay National Estuarine Research Reserve, National Oceanic and Atmospheric Administration, Everglades National Park, Big Cypress National Preserve, Ten Thousand Islands National Wildlife Refuge, Florida Automated Weather Network of the University of Florida Institute of Food and Agriculture Extension, and United States Geological Survey. We thank the Fish and Wildlife Research Institute division of the Florida Fish and Wildlife Conservation Commission for synoptic aerial survey data. We thank Susan Butler and Dean Easton for their help with data acquisition and 
Andrea Bowling for manuscript proofing. Partial funding was provided by the following USGS programs: Place-Based Studies (PBS), Priority Ecosystems Science (PES), and Critical Ecosystem Studies Initiative (CESI). Use of trade or product names does not imply endorsement by the U.S. Government. The findings and conclusions in this article are those of the authors and do not necessarily represent the views of the U.S. Fish and Wildlife Service.

Open Access This article is distributed under the terms of the Creative Commons Attribution Noncommercial License which permits any noncommercial use, distribution, and reproduction in any medium, provided the original author(s) and source are credited.

\section{References}

Ackerman, B.B. 1995. Aerial surveys of manatees: a summary and progress report. In Population Biology of the Florida Manatee (Trichechus manatus latirostris), eds. T. J. O'Shea, B. B. Ackerman, and H. F. Percival, 13-33. National Biological Service, Information and Technology Report 1. 289 pp.

Baron, J.S., B. Griffith, L.A. Joyce, P. Kareiva, B.D. Keller, M.A. Palmer, C.H. Peterson, and J.M. Scott. 2008. Preliminary review of adaptation options for climate-sensitive ecosystems and resources. A Report by the U.S. Climate Change Science Program and the Subcommittee on Global Change Research, eds. S.H. Julius and J.M. West. U.S. Environmental Protection Agency, Washington, DC, USA, 873 pp. http://www.globalchange.gov/ publications/reports/scientific-assessments/saps. Accessed 17 August 2009.

Barton, S.L. 2006. The influence of habitat features on selection and use of a winter refuge by manatees (Trichechus manatus latirostris) in Charlotte Harbor, Florida. M.S. Thesis, University of South Florida, Tampa, $66 \mathrm{pp}$.

Bossart, G.D. 2001. Manatees. In CRC handbook of marine mammal medicine, ed. L.A. Dierauf and F.M.D. Gulland, 939-960. Boca Raton: CRC Press.

Bossart, G.D., R.A. Meisner, S.A. Rommel, S.-J. Ghim, and A.B. Jenson. 2003. Pathological features of the Florida manatee cold stress syndrome. Aquatic Mammals 29(1): 9-17.

Browder, J., A. Dragovich, J. Tashiro, E. Coleman-Duffie, C. Foltz, J. Zweifel. 1986. A comparison of the biological abundances in three adjacent bay systems downstream from the Goldgn Gate Estates canal system. Technical Memorandum NMFS-SEFC-185. National Oceanographic and Atmospheric Administration, Miami, Florida.

Campbell, H.W. and A.B. Irvine. 1981. Manatee mortality during the unusually cold winter of 1976-1977. In The West Indian manatee in Florida. Proceedings of a workshop held in Orlando, eds. R. L. Brownell, Jr. and K. Ralls, 86-91. FL, 2729 March 1978. Florida Department of Natural Resources, Tallahassee. $154 \mathrm{pp}$.

Deutsch, C.J., J.P. Reid, R.K. Bonde, D.E. Easton, H.I. Kochman, and T.J. O'Shea. 2003. Seasonal movements, migratory behavior, and site fidelity of West Indian Manatees along the Atlantic coast of the United States. Wildlife Monographs 151: 1-77.

Dyer, K.R. 1997. Estuaries: a physical introduction, 2nd ed, 195. N. Y.: J. Wiley and Sons.

Edwards, H.H., K.H. Pollock, J.E. Reynolds III, and J.A. Powell. 2007. Estimation of detection probability in manatee aerial surveys at a winter aggregation site. Journal of Wildlife Management 71: 2052-2060.

E.S.R.I. 2007. Environmental Systems Research Institute, Inc. Redlands, CA, USA.
Fitterman, D. and M. Deszcz-Pan. 2001. Saltwater intrusion in Everglades National Park, Florida measured by airborne electromagnetic surveys. First International conference on Saltwater Intrusion and Coastal Aquifers Monitoring, Modeling and Management. 23-25

Fofonoff, P., and R.C. Millard Jr. 1983. Algorithms for computation of fundamental properties of seawater. UNESCO Technical Papers in Marine Science No. 44.

FWRI 2009. http://ocean.floridamarine.org/mrgis_ims/Description Layers_Marine.htm

Hamilton, D.P., T. Chan, M.S. Robb, C.B. Pattiaratchi, and M. Herzfeld. 2001. The hydrology of the upper Swan River estuary with focus on an artificial destratification trial. Hydrological Processes 15: 2465-2480.

Hamrick, J. M., 1992. A Three-Dimensional Environmental Fluid Dynamics Computer Code: Theoretical and Computational Aspects. The College of William and Mary, Virginia Institute of Marine Science. Special Report 317, 63 pp.

Hartman, D.S. 1979. Ecology and behavior of the manatee (Trichechus manatus) in Florida. American Society of Mammalogists Special Publication 5: 1-153.

Hollander, M., and D.A. Wolfe. 1999. Nonparametric statistical methods, 2nd ed. New York: John Wiley \& Sons.

Hothorn, T., K. Hornik, M.A. van de Wiel, and Zeileis Achim. 2008. Implementing a class of permutation tests: the coin package. Journal of Statistical Software 28(8): 1-23. http://www.jstatsoft. org/v28/i08/.

Ibanez, C., D. Pont, and N. Prat. 1997. Characterization of the Ebre and Rhone estuaries: a basis for defining and classifying saltwedge estuaries. Limnology and Oceanography 42: 89-101.

Irvine, A. 1983. Manatee metabolism and its influence on distribution in Florida. Biological Conservation 25: 314-334.

Kimmerer, W. 2004. Open water processes of the San Francisco Estuary: from physical forcing to biological responses. San Francisco Estuary and Watershed Science [online serial]. Vol 2, Issue 1 (February 2004), Article 1.

Kurup, R.G., D.P. Hamilton, and J.C. Patterson. 1998. Modelling the effect of seasonal flow variations on the position of salt wedge in a microtidal estuary. Estuarine, Coastal and Shelf Science 47: 191-208.

Kurup, R.G., and D.P. Hamilton. 2002. Flushing of dense, hypoxic water from a cavity of the Swan River Estuary, Western Australia. Estuaries 25(5): 908-915.

Laist, D.W., and J.E. Reynolds. 2005a. Influence of power plants and other warm-water refuges on Florida manatees. Marine Mammal Science 21: 739-765.

Laist, D.W., and J.E. Reynolds. 2005b. Florida manatees, warm-water refuges, and an uncertain future. Coastal Management 33: 279 295.

Langtimm, C.A., E.D. Swain, B.M. Stith, J.P. Reid, D.H. Slone, J. Decker, S.M. Butler, T. Doyle, and R.W. Snow. 2009. Integrated Science: Florida Manatees and Everglades Hydrology. USGS Fact Sheet 2009-3002.

Lefebvre, L.L., T.J. O’Shea, G.B. Rathbun, and R.C. Best. 1989. Distribution, status and biogeography of the West Indian manatee. In Biogeography of the West Indies; past, present, and future, ed. C.A. Woods, 567-610. Gainesville: Sandhill Crane Press.

Linderfelt, W.R., and J.V. Turner. 2001. Interaction between shallow groundwater, saline surface water and nutrient discharge in a seasonal estuary: the Swan-Canning system. Hydrological Processes 15: 2631-2653.

Luther III, G.W., S. Ma, R. Trouwborst, B. Glazer, M. Blickley, R.W. Scarborough, and M.G. Mensinger. 2004. The roles of anoxia, $\mathrm{H} 2 \mathrm{~S}$ and storm event in fish kills of dead end canals of Delaware Inland Bays. Estuaries 27(3): 551-560. 
Mann, K.H., and J.R.N. Lazer. 2006. Dynamics of marine ecosystems, 3rd ed, 496. Malden: Blackwell.

Matthews, W.J. 1998. Patterns in freshwater fish ecology, London: Chapman and Hall. 756 pp.

Moore, J.C. 1951. The range of the Florida manatee. The Quarterly Journal of the Florida Academy of Sciences 14: 1-19.

Price, R.M., and P.K. Swart. 2006. Geochemical indicators of groundwater recharge in the surficial aquifer system, Everglades National Park, Florida, USA. Geological Society of America Special Paper 404: 251-266.

Reid, G.K., and R.D. Wood. 1976. Ecology of inland waters and estuaries, N.Y.: D. Van Nostrand Co., 485 pp.

Reid, J.P., R.K. Bonde, and T.J. O'Shea. 1995. Reproduction and mortality of radio-tagged and recognizable manatees on the Atlantic coast of Florida. Pp. 171-191 in O'Shea T. J., B. B. Ackerman and H. F. Percival, Eds. Population Biology of the Florida Manatee. National Biological Service, Information and Technology Report 1. 289 pp.

Rodgers, A.R. and A.P. Carr. 1998. HRE: the home range extension for ArcView. User's manual, 27 p. Centre for Northern Forest Ecosystem Research, Ontario Ministry of Natural Resources, Thunder Bay, Ontario, Canada.

Runge, M. C., C. A. Sanders-Reid, C. A. Langtimm, and C. J. Fonnesbeck. 2007. A quantitative threats analysis for the Florida manatee (Trichechus manatus latirostris). U.S. Geological Survey Open-File Report 2007-1086, <http://www.pwrc.usgs. gov/resshow/manatee/\#threats>. Accessed 21 April 2009.

Schaefer, J.F., E. Marsh-Matherws, D.E. Spooner, K.B. Gido, and W.J. Mathews. 2003. Effects of barriers and thermal refugia on local movement of the threatened darter, Percina pantherina. Environmental Biology of Fishes 66: 391-400.

Service Argos, Inc. 1996. User's manual, 176. Landover: Service Argos, Inc.

Shafland, P.L. 1995. Introduction and establishment of a successful butterfly peacock fishery in southeast Florida canals. American Fisheries Society Symposium 15: 443-451.

Shane, S.H. 1984. Manatee use of power plant effluents in Brevard County, Florida. Florida Scientist 47: 180-188.

Silverman, B.W. 1986. Density estimation for statistics and data analysis. London: Chapman and Hall.

Smith, A.J., and J.V. Turner. 2001. Density-dependent surface watergroundwater interaction and nutrient discharge in the SwanCanning Estuary. Hydrological Processes 15: 2595-2616.
Stith, B.M., D.H. Slone, and J.P. Reid. 2006. Review and synthesis of manatee data in Everglades National Park. USGS Administrative Report, 126. Gainesville: USGS Florida Integegrated Science Center.

Surge, D.M., and K.C. Lohmann. 2002. Temporal and spatial differences in salinity and water chemistry in SW Florida estuaries: effects of human-impacted watersheds. Estuaries 25: 393-408.

Swain, E., and J. Decker. 2009. Development, testing, and application of a coupled hydrodynamic surface-water/ground-water model (FTLOADDS) with heat and salinity transport in the TenThousand Islands/Picayune Strand restoration project area, Florida. Scientific Investigations Report 2009-5146. 83 pp.

Torgersen, C.E., D.M. Price, H.W. Li, and B.A. McIntosh. 1999. Multiscale thermal refugia and stream habitat associations of chinook salmon in northeastern Oregon. Ecological Applications 9(1): 301-319.

Trexler, J.C., W.F. Loftus, F. Jordan, J.J. Lorenz, J.H. Chick, and R.M. Kobza. 2000. Empirical assessment of fish introductions in a subtropical wetland: an evaluation of contrasting views. Biological Invasions 2: 265-277.

U.S. Army Corp of Engineers and South Florida Water Management District. 2004. Comprehensive Everglades Restoration Plan, Picayune Strand Restoration (formerly Southern Golden Gate Estates Ecosystem Restoration). Final integrated project implementation report and environmental impact statement. $<\mathrm{http} / /$ www.evergladesplan.org/pm/projects/docs_30_sgge_pir_final. aspx>. Accessed June 2009.

U.S. Environmental Protection Agency. 1975. Finger-fill canal studiesFlorida and North Carolina. EPA 904/9-76-017. 233 pp.

U.S. Environmental Protection Agency. 2002. Environmental Fluid Dynamics Code (EFDC): accessed at http://www.epa.gov/athens/ wwqtsc/html/efdc.html on 2/19/2009.

U.S. Fish and Wildlife Service. 2001. Florida Manatee Recovery Plan, (Trichechus manatus latirostris), Third Revision. U.S. Fish and Wildlife Service. Atlanta, Georgia. 144 pp. + appendices.

Venables, W.N., and B.D. Ripley. 2002. Modern applied statistics with $S$, 4th ed. N.Y., N.Y: Springer Science and Business Media.

Worton, B.J. 1989. Kernel methods for estimating the utilization distribution in home-range studies. Ecology 70: 164-168.

$\mathrm{Xu}$, H., J. Lin, and D. Wang. 2008. Numerical study on salinity stratification in the Pamlico River Estuary. Estuarine, Coastal and Shelf Science 80: 74-84. 